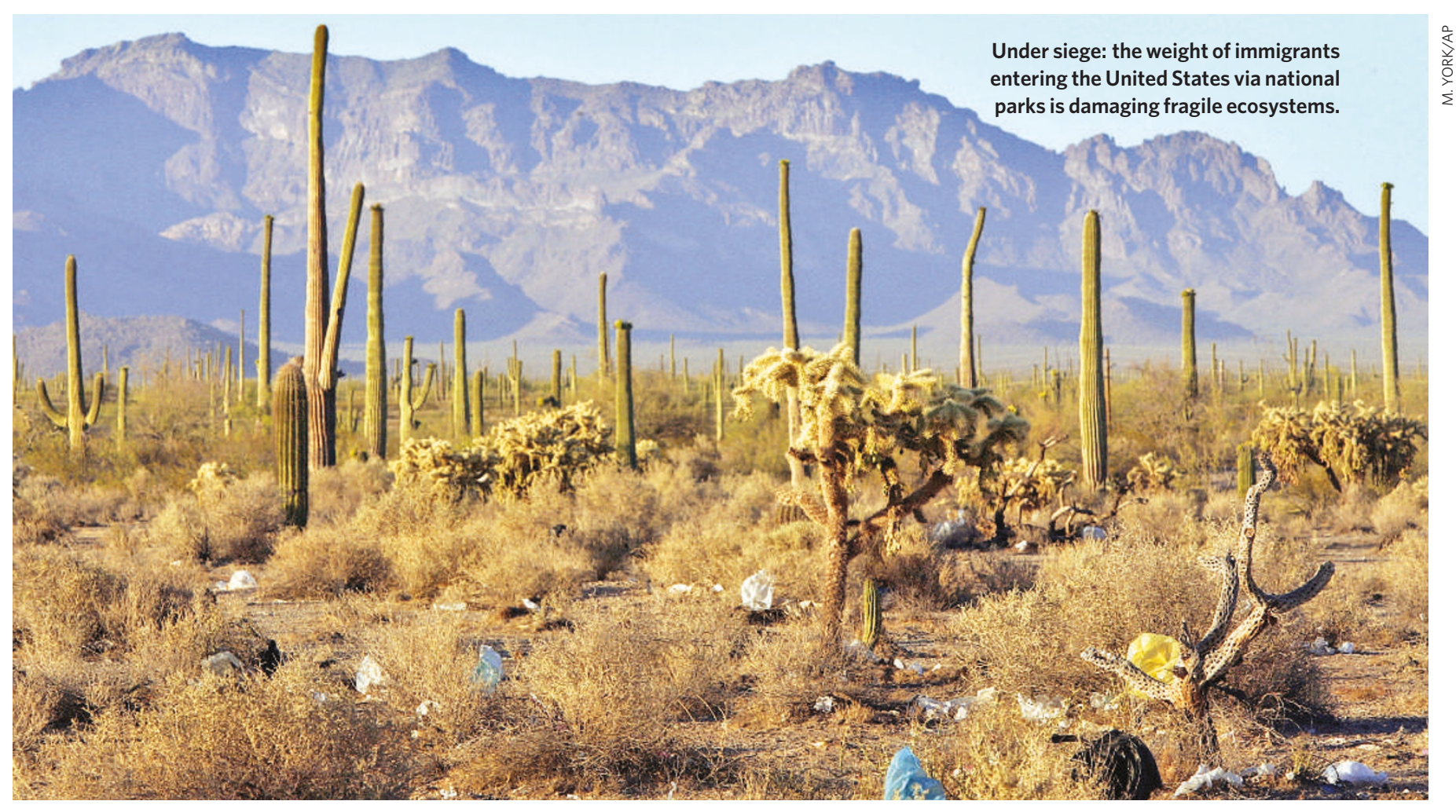

\title{
Wildlife caught in crossfire of US immigration battle
}

$\mathrm{R}$ ichard Felger, a conservationist who runs the Drylands Institute in Tucson, Arizona, used to stop and share coffee with people he met crossing the desert along the US-Mexico border. Not any more. A couple of summers ago he was robbed at gunpoint in the Sierra Madres by some drug runners. Another time he was almost carjacked. "You can't tell who's friendly anymore," he says.

Felger and other conservation biologists say that the biologically valuable lands along the border have become a war zone; increasing numbers of migrants and drug-traffickers are travelling north via the desert, which means more Border Patrol agents pursuing them in cars and helicopters. The dangers are making research into how all the activity is affecting the region's endangered wildlife impossible. But researchers warn that proposals to erect hundreds of kilometres of fences and roads to try to stop the illegal crossings will damage many of the fragile species even further.

The US-Mexico border is one of the longest policed borders in the world, stretching some $3,200 \mathrm{~km}$. Cutting through the Colorado river delta, it then runs through the Sonoran Desert for much of its western length. The area is a conservation priority because its rich biodiversity is threatened by a declining water supply humans use nearly all the water in the Colorado river. It hosts more plant species than any other desert, as well as vulnerable animals including the pronghorn antelope, and species of bat, owl and jaguar.

Over the past decade or so, tougher border enforcement at major crossings such as San Diego in California and El Paso in Texas, has squeezed migrants and drug runners out into the desert. That's making life dangerous for local wildlife, and the biologists studying it.

"The Sonoran Desert system can be pretty fragile," says Kathy Billings, chief ranger of the desert's Organ Pipe Cactus National Monument park. Billings began her job not long after ranger Kris Eggle was shot and killed when on duty in a drug-related pursuit in 2002. Billings describes the illegal trails beaten into the desert by immigrants and smugglers. The desert is spangled with

trash - nappies, toothbrushes, backpacks and water bottles painted black for night walking. In places, "the smell of human waste is overwhelming", she says. About a third of the park is now closed to visitors, and researchers must frequently be accompanied by armed guards.

"Today these groups are often carrying drugs and are a lot more dangerous," adds Mark Briggs, a restoration ecologist who has worked with the conservation group the WWF, and Big Bend National Park in Texas. "I've had some

\section{"The smell of fairly frightening experiences. But human waste is go on with theirs."}

The dangers mean that data on how badly the environment is being damaged are scarce. "It's a joke to say we can do pygmy-owl surveys with the amount of activity you see down there," says Jenny Neeley, southwest representative of Defenders of Wildlife. Neely, based in Phoenix, Arizona, is co-author of a report about how illegal immigrants and the Border Patrol hurt wildlife.

Peter Morrison, director of the Pacific 
Biodiversity Institute in Winthrop, Washington, has been able to do some research on the problem. In a survey of the Buenos Aires National Wildlife Refuge, for example, he recorded an average of $4 \mathrm{~km}$ of illegal trails per square kilometre of land. Half the trails were found in the habitat of the endangered Pima pineapple cactus. Morrison presented his results last month at the annual meeting of the Society for Conservation Biology in San Jose, California. But he and his colleagues are now avoiding certain areas. "It's getting a bit scary," he says. "A lot of people in the field are questioning whether they want to keep doing this work."

This election season, US politicians have focused their attention on the problems at the border. In the past couple of months President George W. Bush has sent thousands of National Guard troops to aid the 9,000strong Border Patrol. And duelling bills in the House and Senate propose hundreds of kilometres of extra fencing and illuminated roads. "We are going to see some fencing built, and some roads built," says Marshal Fitz, director of advocacy for the American Immigration Lawyers Association based in Washington DC. "It's just a matter of how much and when."

But although conservationists are pleased that attention is being paid to the situation, they are horrified by the influx of troops and the proposed fences. "What they are putting up is like a Berlin wall, and the border-control guys are creating roads left and right," says Briggs. "It has been a huge setback for the wildlife."

"It's very important to try to maintain a

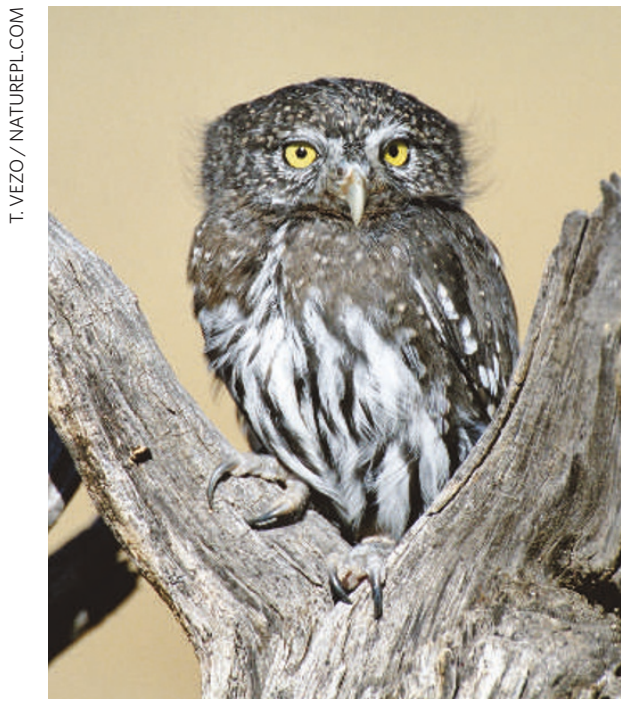

The Sonoran Desert, a highway for drug traffickers, is also home to the endangered northern pygmy owl. wildlife-friendly border," agrees Morrison. "If we put up a 12- or 25-foot high wall, it stops everything except things that fly from crossing. That would be a real disaster in the long term."

Researchers are particularly worried about the easily spooked migratory Sonoran pronghorn antelope. Fences would fragment the endangered antelope populations into even smaller groups, and the extra stress caused by border-control traffic might push them over the brink. Meanwhile trash piles attract ravens, which might eat threatened tortoises, and all-night lights disrupt bugs, bats and nocturnal cats such as the ocelot andi.

There is an alternative to solid fences. Last month, Organ Pipe installed a steel rail, one metre off the ground, which stops cars and trucks yet allows wildlife through. Park biologist Tim Tibbets says that since the barrier, funded by the National Park Service, was erected, vehicle traffic has virtually stopped. Other parks and the nearby Tohono O'odham Indian reservation are looking into putting up similar barriers. The Border Patrol is experimenting with vehicle barriers and is currently coordinating a $10-\mathrm{km} \mathrm{sec}-$ tion, with a view towards extending that to 133 $\mathrm{km}$, along the Arizona border.

But there seems to be more political support for the heavy-duty barriers. And many argue that fences alone won't solve the problem - in terms of immigration or conservation. "I think there is a heavy militaristic hand in the US response to this," says Briggs. "There's momentum now towards putting in these large fences... I don't see anyone addressing why immigrants are coming in the first place."

"No matter what kind of wall we put up we are going to have problems," says Morrison. "The fundamental solution will be to reduce the incredible economic disparity between the countries."

In the meantime, Neeley and Defenders of Wildlife contend that the Border Patrol has neglected the environmental impacts of its work, and has not fulfilled its legal responsibilities under the Endangered Species Act.

In a statement to Nature the Border Patrol said: "Our primary responsibility is to prevent terrorists and their weapons from entering the country... We will continue to move forward and work with other federal agencies to minimize our effects on the environment." But in an informal conversation, a Border Patrol spokesman said he felt that conservation projects are just not on the agency's radar screen.

"There are owls on the southwest border?" he added.

Emma Marris
ON THE RECORD

ccommon sense tells you that you want professionals trained to the Nth degree to do jobs like astronaut jobs.”

Astronaut Jerry Linenger disapproves of plans by a private company to offer spacewalks to the public - at a total cost of $\$ 35$ million.

\section{c(Danger! Water contains high levels of hydrogen."}

Officials in Louisville, Kentucky, post signs to discourage residents from playing in the city's fountains.

Sources: Washington Post, Louisville Courier Journal

\section{SCORECARD}

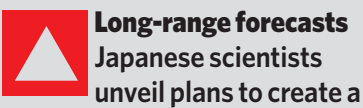

30-year weather forecast using their Earth Simulator supercomputer.

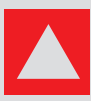

Plants in space

China announces that it will launch a satellite this autumn solely to breed seeds in microgravity.

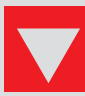

Australian science A government audit shows that Australia may face a shortage of 20,000 scientists and engineers by 2012.

\section{NUMBER CRUNCH}

The Union of Concerned Scientists recently surveyed 997 researchers at the US Food and Drug Administration (FDA) and found:

$70 \%$ believe the agency lacks the resources to protect public health.

$60 \%$ knew of commercial interference in the FDA process.

$18 \%$ had been asked to inappropriately exclude or alter technical information or their conclusions.

$40 \%$ said they could not publicly express concerns about public health without fear of retaliation.

Source: Union of Concerned Scientists

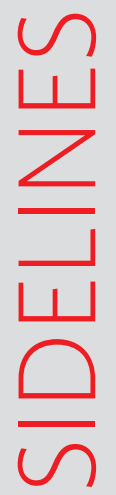

